\title{
Milk-alkali syndrome (MAS) as a complication of the treatment of hypoparathyroidism - a case study
}

\author{
Zespół mleczno-alkaliczny (MAS) jako powikłanie leczenia niedoczynności \\ przytarczyc — opis przypadku
}

\author{
Agata Skwarek, Janusz Pachucki, Tomasz Bednarczuk, Zuzanna Żurecka, Michał Popow, \\ Agnieszka Kondracka, Zbigniew Bartoszewicz
}

Department of Internal Medicine and Endocrinology, Medical University of Warsaw, Warsaw, Poland

\begin{abstract}
Milk-alkali syndrome (MAS) is a severe and life-threatening complication of the treatment of hypoparathyroidism characterised by renal failure, metabolic alkalosis, and hypercalcaemia. The clinical course often begins abruptly and without prodromal symptoms. Although it is closely related to the doses of calcium carbonate and active vitamin D preparations, its occurrence does not depend on the duration of hypoparathyroidism treatment. Among other factors triggering MAS are drugs influencing the glomerular filtration rate (angiotensin receptor blockers, sartans, aldosterone receptor antagonists, thiazide diuretics), lack of adequate control measures during hypoparathyroidism treatment, changes in calcium carbonate supplementation, dehydration, a diet rich in pH-basic foods (i.e. vegetarian diet), and pregnancy. A higher calcium carbonate dose is directly associated with an increased risk of milk-alkali syndrome. In cases of high calcium demand it is necessary to control renal function and monitor the level of serum calcium frequently, aiming for the lower end of the reference range. If MAS is confirmed or there are alarming neurological symptoms suggestive of hypercalcaemia, immediate hospitalisation is required. Treatment of MAS involves discontinuing calcium and vitamin D supplementation and administering an intravenous infusion of normal saline solution to eliminate volume deficiencies and achieve forced diuresis while maintaining proper fluid balance. As soon as there is improvement in the clinical condition, it is necessary to begin treatment of comorbidities increasing the risk of renal failure or alkalosis (i.e. vomiting, diarrhoea). (Endokrynol Pol 2018; 69 (2): 200-204)
\end{abstract}

Key words: MAS, hypercalcemia, hypoparathyroidism, alkalinisation, hypercalciuria, milk alkali syndrome, metabolic alkalosis, renal failure, active vitamin $D$

\section{Streszczenie \\ Zespół Burnetta (milk-alkali syndrome, MAS), cechujący się niewydolnością nerek, zasadowicą metaboliczną i hiperkalcemią, jest ciężkim i zagrażającym życiu powikłaniem leczenia niedoczynności przytarczyc. Przebieg kliniczny jest często nagły i niepoprzedzony żadnymi objawami prodromalnymi. Wystąpienie zespołu Burneta nie zależy od czasu leczenia niedoczynności przytarczyc, mimo że jest on ściśle związany ze stosowaną terapią, zwłaszcza wielkością dawki węglanu wapnia i aktywnych preparatów witaminy D. Jako czynniki wy- wołujące zespół Burnetta wymienia się między innymi leki wpływające na filtrację kłębuszkową (inhibitory receptorów angiotensyny, sartany, antagoniści receptora aldosteronu, diuretyki tiazydowe), brak odpowiedniej rutynowej kontroli, zmiany suplementacji węglanu wapnia, odwodnienie, dietę bogatą w produkty o zasadowym pH (tj. dieta wegetariańska), ciążę itp. Większe dawki węglanu wapnia wiążą się bezpośrednio ze zwiększonym ryzykiem zespołu Burnetta. W przypadku wysokiego zapotrzebowania na wapń konieczne jest częstsze kontrolowanie czynności nerek i monitorowanie stężeń wapnia w surowicy; przy czym należy się starać utrzymać stężenie wapnia w górnym zakresie wartości prawidłowych. W przypadku potwierdzenia zespołu Burnetta lub jeśli występują alarmujące obja- wy neurologiczne świadczące o hiperkalcemii, należy niezwłocznie skierować chorego do szpitala. Leczenie zespołu Burnetta obejmuje: zaprzestanie suplementacji wapnia i witaminy D, dożylną infuzję soli fizjologicznej w celu uzupełnienia niedoborów objętościowych oraz wywołanie wymuszonej diurezy przy jednoczesnym utrzymaniu odpowiedniego bilansu płynów. Kiedy tylko stan kliniczny chorego się poprawi, należy rozpocząć leczenie zaburzeń wspólistniejących zwiększających ryzyko niewydolności nerek lub zasadowicy (wymioty, biegunka). (Endokrynol Pol 2018; 69 (2): 200-204)}

Słowa kluczowe: zespół Burnetta, hiperkalcemia, niedoczynność przytarczyc, alkalizacja, hiperkalciuria, zespół mleczno-alkaliczny, zasadowica metaboliczna, niewydolność nerek, aktywna witamina $D$

\section{Introduction}

Treating patients suffering from symptomatic postoperational hypoparathyroidism with active vitamin D metabolites, calcium carbonate supplements, and a strict low-phosphate diet is difficult. The goal is to achieve a clinically asymptomatic state, with particular care given to avoiding tetany seizures. Attempting to stabilise the calcium level at any cost [1], however, is not recommended since it may lead to severe complications, such as: 
- calcifications in the brain, kidney, heart, and blood vessels;

- hypercalciuria leading to nephrolithiasis;

- milk-alkali syndrome - MAS.

Deposition of calcium phosphate in soft tissues, including the brain, is related to its chemical properties. Precipitation of calcium salts in the skin and subcutaneous tissues known as metastatic calcinosis cutis is, in our experience, caused by disturbances in calciumphosphate metabolism unrelated to the pathology of MAS. The risk of deposit formation in MAS is increased in patients requiring multiple calcium infusions to alleviate tetany attacks during hyperphosphataemia. Excessive supplementation of active vitamin D also increases the likelihood of calcium deposit formation because it increases the absorption of both calcium and phosphate. Chronic hyperphosphataemia is a known risk factor for premature death, especially in patients suffering from kidney failure [2]. In patients with appropriate kidney function, increased phosphate levels predispose to calcium-phosphate deposition in soft tissue, especially surrounding the basal ganglia. This is due to respond of PIT 1 [3] and PIT $2[4,5]$ sodium phosphate contransporters to increase phosphate level in serum. This leads to overload of Pi cells and begins a chronic salting-out process of hydroxyapatite crystals [6]. Analysis using the calcium phosphate product is not always helpful. Incidental calcaemia values in patients with hypoparathyroidism are low. Our own studies demonstrated a transient increase in the calcium phosphate product after solitary administration of high doses of calcium.

\begin{tabular}{ll}
$\begin{array}{l}\text { Calcium-Phosphate Product } \\
\mathrm{Ca} \times \mathrm{P}\end{array}$ & $\begin{array}{l}\text { Reference Range }<55 \mathrm{mg}^{2} / \mathrm{dl}^{2} \\
\left(<4.4 \mathrm{mmol}^{2} / \mathrm{I}^{2}\right)\end{array}$ \\
\hline
\end{tabular}

Hypercalciuria is a constant feature of hypoparathyroidism, even if calcium concentrations in the serum are within the reference range. Active vitamin $\mathrm{D}$ preparations prescribed to control the symptoms of hypoparathyroidism are often given in doses that significantly exceed the physiological level. Therefore, thiazide diuretics are used in some patients despite their yet undocumented effect on renal stone formation and other complications of hypoparathyroidism treatment.

\section{Milk-alkali syndrome — definition}

In the past, milk-alkali syndrome (also referred to as calcium-alkali syndrome) was associated with excessive use of sodium bicarbonate, calcium carbonate, sucralfate, milk, and cream in the treatment of peptic ulcer disease (PUD). MAS was diagnosed on the basis of the following triad of symptoms: metabolic alkalosis, hypercalcaemia, and renal failure. Early case descriptions date back to the 1920s. In 1936 Cuthbert Cope described cases of hypermagnesaemia, hyperphosphataemia, hypercalcaemia, alkalosis, renal failure, and their close relationship to the complications of peptic ulcer treatment. He observed an improvement in kidney function after discontinuation of the treatment, which led him to conclude that the renal impairment had caused the illness. In 1949 Charles Burnett described cases of MAS in patients treated only with sodium carbonate, without calcium salts or milk. In his research he emphasised the fact that not all patients suffered from hyperphosphataemia and irreversible renal failure, and biochemical dysfunctions were often accompanied by calcium depositions in soft tissues. Presently it is believed that both scholars were describing the same disease at different stages. Some scientists still distinguish among three different types of MAS: acute (Cope's), chronic (Burnett's), and an intermediate sub-acute form. In certain cases the rate at which symptoms recede determines the form of the disease: normalisation of renal function test values and calcium levels within a few days indicates the acute type, no improvement over several days despite appropriate treatment indicates a chronic nature of the disease, while the remaining, in-between forms indicate the sub-acute type.

In recent years the treatment of PUD has changed and MAS is now mostly recognised in:

- post-menopausal women prescribed calcium carbonate and vitamin D supplements to prevent/treat osteoporosis;

- pregnant women taking calcium supplements;

- bulimic patients suffering from chronic alkalosis;

- persons undergoing dialysis and treatment based on active vitamin $\mathrm{D}$ and calcium carbonate supplementation (alkalising medications);

- persons being treated for hypoparathyroidism or, less often, alleged hypoparathyroidism.

\section{MAS pathomechanism in patients treated for hypoparathyroidism}

The elevated calcium level present during the development of MAS is caused by both excessive ingestion of calcium and its impaired process of elimination from the body.

There are a few critical elements controlling the absorption of calcium in the gastrointestinal tract:

- Active vitamin D (calcitriol) influences the expression of genes through its nuclear receptors, directly and indirectly increasing the absorption of calcium from the gastrointestinal tract. Therefore, excessive intake of the active form of vitamin D increases the risk of hypercalcaemia [7-10]; 
- Increased calcium intake, as well as alkalisation of intestinal content (buffering of gastric acid), increases the absorption of calcium from the gastrointestinal tract $[11,12]$;

- Sodium and water loss due to diarrhoea reduces the intravascular volume, which in turn activates the renin-angiotensin-aldosterone system and stimulates alkalosis. A decrease in the glomerular filtration rate associated with intravascular volume depletion impedes the excretion of calcium and bicarbonates [9, 10, 13];

- Stimulation of the calcium receptor (CaS-R) caused by an elevated calcium level in the blood reduces the sensitivity of aquaporin receptors to vasopressin. Excessive calcium ingestion causes hypercalcaemia, which activates the calcium receptor. This intensifies diuresis and further reduces the volume of the vascular bed, leading to secondary activation of the renin-angiotensin-aldosterone system, and finally resulting in renal failure and decreased urinary calcium excretion $[9,10,13]$;

- Metabolic alkalosis activates adapting mechanisms such as releasing hydrons from the "bone buffer". Normalisation of phosphate levels observed in hypoparathyroidism indicates the vital clinical role of bone metabolism in patients with MAS. Phosphate levels decrease in spite of significantly impaired renal function. This could be explained by tricalcium phosphate synthesis in the bones. This process is accompanied by the release of hydrons, which neutralize the alkaline $\mathrm{pH}$ value [14].

The variety in pathogenic mechanisms of MAS development in patients suffering from hypoparathyroidism is partially dependent upon the occurrence of different triggering factors. The most common factors are:

- dehydration and/or compromised renal function (i.e. diuretic use, nephrotoxic medications, contrast agents);

- a plant-based vegan or vegetarian diet (increased tendency towards alkalisation of the body);

- excessive treatment with active analogues of vitamin $\mathrm{D}$ and calcium carbonates, causing exaggerated normalisation of calcium levels in the serum;

- parallel intake of medications affecting the glomerular filtration rate (i.e. angiotensin-converting enzyme inhibitors).

\section{MAS clinical case study}

A 45-year-old woman with symptomatic intractable postoperative hypoparathyroidism, not adhering to a low-phosphate diet, was being treated with $4 \mathrm{~g}$ of calcium carbonate, 1000 I.U. cholecalciferol, $1 \mu \mathrm{g}$
Table I. Follow-up blood tests during the treatment of hypoparathyroidism and sub-acute milk-alkali syndrome

Table I. Kontrolne badania krwi w trakcie leczenia chorego z niedoczynnościq przytarczyc i podostrym zespołem Burnetta

\begin{tabular}{lcc}
\hline & Hypoparathyroidism & $\begin{array}{c}\text { Milk-alkali } \\
\text { syndrome }\end{array}$ \\
\hline Ca $(2.15-2.6 \mathrm{mmol} / \mathrm{l})$ & 1.72 & 4.1 \\
\hline PO4 (0.81-1.5 mmol/l) & 2.05 & 0.99 \\
\hline ALP (38-126 U/l) & 103 & 449 \\
\hline Creatinine (0.5-1.3 mg/dl) & 0.88 & 6.72 \\
\hline GFR (MDRD) (> 60) & $>60$ & 6.7 \\
\hline Ca - calcium; P04 - phosphate; ALP - alkaline phosphatase; GFR (MDRD) &
\end{tabular}

Table II Bone turnover markers during sub-acute type MAS

Table II Markery obrotu kostnego w trakcie epizodu podostrego zespotu Burnetta

\begin{tabular}{ll} 
& Milk-alkali syndrome \\
\hline FGF $23(20-50 \mathrm{pg} / \mathrm{ml})$ & 13.84 \\
\hline Pro-collagen 1N terminal (15-59) & 240.9 \\
\hline Osteocalcin (11-43 ng/ml) & 143.5 \\
\hline DXA L1-L4 Z score & +6.9 \\
\hline DXA of the femoral neck Z score & +3.6 \\
\hline DXA of the core of the radius Z score & +1.5 \\
\hline
\end{tabular}

FGF 23 - fibroblast growth factor; DXA - bone densitometry using doublebeam radiation; L1 — first lumbar vertebra; L4 — fourth lumbar vertebra

alfacalcidol, magnesium supplements and, temporarily, aluminium salts. She was admitted to the emergency department after her routine measurement of serum calcium levels was markedly elevated. The patient had independently increased her calcium carbonate dose around her menstrual period. MAS-related hypercalcaemia was diagnosed based on the clinical picture and results of additional tests (Table I, II).

Tetany treatment may mask MAS symptoms and delay diagnosis. Presenting symptoms may be similar to those characteristic of hypercalcaemic crises, such as:

- apathy;

— imbalance;

- weakness;

- constipation;

- nausea;

- abdominal pain.

The following are deviations in the biochemical analysis of patients with MAS:

- hypercalcaemia;

- decreased glomerular filtration rate (GFR);

- normalisation of phosphataemia; 
- late-onset metabolic alkalosis, probably related to the impairment of bone buffering mechanisms as well as the aggravation of renal dysfunction.

\section{MAS prevention and monitoring}

The following measures help prevent the development of MAS and MAS-related complications in patients with hypoparathyroidism:

- avoiding (if possible) exceeding the calcium carbonate dose limit of $10 \mathrm{~g}$ (approx. $5 \mathrm{~g}$ of elemental calcium);

- prescribing active vitamin D (alfacalcidol or calcitriol) in the lowest possible dose sufficient to control symptoms, but not enough to lead to normocalcaemia;

- aiming for reduction rather than elimination of symptoms during the treatment of hypoparathyroidism in order to normalise the serum calcium level;

- recommending a low-phosphate diet based on avoiding processed and preserved foods;

- restricting the use of compounds impairing phosphate absorption, such as magnesium or aluminium salts. Chronic treatment may lead to aluminium deposits in bones, causing bone damage and aluminium osteopathy. Moreover, depositions of aluminium salts in the central nervous system may disturb cognitive functions. [7, 8].

Due to the statistically rare occurrence of MAS, preventative measures are predominantly based upon empirical knowledge or expert recommendations, rather than on evidence-based medicine (EBM). They are as follows:

- routine monitoring of calcium, phosphate, and creatinine levels in all patients requiring nonphysiological doses of vitamin $\mathrm{D}$ and calcium preparations. Monitoring only calcium and phosphate levels may delay diagnosis of MAS. The dosage of calcium supplementation may be aided by diurnal measurements of the urinary calcium excretion rate, as well as assessment of the calcium clearance ratio. Additionally, monitoring helps estimate renal function;

- calcium level measurement 14 days after starting treatment or after changing the dosage of medications prescribed for hypoparathyroidism;

- calcium level measurement 14 days after prescribing medications influencing the GFR (thiazide diuretics, I-ACE, sartans, spironolactone);

- avoiding dehydration through adequate fluid consumption;

- educating patients on issues related to dietary adherence and the need for medical attention in case of temporary and/or transient recession of tetany symptoms;

- frequent monitoring of vegetarian patients and patients following a diet rich in basic/alkaline foods;

- sudden clinical improvement, especially in patients who have been suffering from chronic calcium deficiency (tetany seizures), should be followed by careful evaluation of the calcium-phosphate concentrations and renal function. It must be emphasised that the occurrence of MAS is not related to the duration of hypoparathyroidism, but rather to a yet unknown triggering factor [15];

- temporary intake of parathyroid hormone analogue, mainly when prescribing oral medication, is not possible. High costs, unknown long-term complications, and intensification of tetany symptoms after the discontinuation of treatment are all disadvantages of this therapy [16];

- cell suspension transplants from parathyroid glands often fail to restore correct calcium homeostasis on a long-term basis. Observations indicated a positive influence of this method on phosphate homeostasis.

\section{MAS treatment}

Only the acute and sub-acute forms of MAS are fully reversible. The treatment consists of:

- hospitalisation with the aim of monitoring treatment;

- elimination of causative factors (e.g. discontinuing potentially nephrotoxic drugs);

- temporary cessation of calcium and vitamin D supplementation;

- intravenous crystalloid infusion, in case of an excessively positive fluid balance and symptoms suggestive of congestive heart failure. Forced diuresis using loop diuretics may be necessary;

- there is currently no foundation for the routine administration of glucocorticosteroids in hypercalcaemia caused by MAS. Their favourable mechanism of action is based on the inhibition of calcitriol synthesis by granulomatous cells or other cells possessing PTH-independent alpha-hydroxylase. The active vitamin D metabolite in MAS is exogenous in nature;

- administering bisphosphonates in hypercalcaemia caused by MAS is controversial. Coexisting disturbances in kidney function, especially those of an advanced nature, are a contraindication. Additionally, the hypothesised mechanism of MAS pathogenesis does not justify antiresorptive therapy;

- treatment with calcitonin causes an increase in the excretion of calcium by the kidneys. Therefore, it 
may be potentially useful in treating MAS-related hypercalcaemia. However, the exact mechanism of action of calcitonin on renal function is still unclear and requires further investigation [17].

\section{Conclusions}

1. Milk-alkali syndrome (MAS) may occur at any stage of hypoparathyroidism.

2. Common triggering factors are dehydration, a vegetarian (alkaline) diet, and treatment with thiazide diuretics.

3. In order to make an early diagnosis of milk-alkali syndrome, it is necessary to routinely monitor calcium, phosphate, and creatinine concentrations in patients being treated for hypoparathyroidism.

4. Rapid resolution of tetany symptoms requires special attention, as well as other cases of unexplained recession of hyperphosphataemia (especially in the absence of dietary modifications).

5. Metabolic alkalosis is a late symptom of MAS and is frequently preceded by impaired renal function.

\section{References}

1. Endres DB. Investigation of hypercalcemia. Clin Biochem. 2012; 45(12): 954 963, doi: 10.1016/j.clinbiochem.2012.04.025, indexed in Pubmed: 22569596.

2. Block GA, Hulbert-Shearon TE, Levin NW, et al. Association of serum phosphorus and calcium $\mathrm{x}$ phosphate product with mortality risk in chronic hemodialysis patients: a national study. Am J Kidney Dis. 1998; 31(4): 607-617, indexed in Pubmed: 9531176.

3. Lemos R, Ramos E, Legati A, et al. Update and Mutational Analysis ofSLC20A2: A Major Cause of Primary Familial Brain Calcification. Human Mutation. 2015; 36(5): 489-495, doi: 10.1002/humu.22778.
4. Virkki LV, Biber J, Murer H, et al. Phosphate transporters: a tale of two solute carrier families. Am J Physiol Renal Physiol. 2007; 293(3): F643-F654, doi: 10.1152/ajprenal.00228.2007, indexed in Pubmed: 17581921.

5. Picard N, Capuano P, Stange G, et al. Acute parathyroid hormone differentially regulates renal brush border membrane phosphate cotransporters. Pflugers Arch. 2010; 460(3): 677-687, doi: 10.1007/s00424-010-0841-1, indexed in Pubmed: 20526720.

6. Cui L, Houston DA, Farquharson C, et al. Characterisation of matrix vesicles in skeletal and soft tissue mineralisation. Bone. 2016; 87: 147-158, doi: 10.1016/j.bone.2016.04.007, indexed in Pubmed: 27072517.

7. Medarov BI. Milk-alkali syndrome. Mayo Clin Proc. 2009; 84(3): 261-267, doi: 10.1016/S0025-6196(11)61144-0, indexed in Pubmed: 19252114.

8. Kolnick L, Harris BD, Choma DP, et al. Hypercalcemia in pregnancy: a case of milk-alkali syndrome. J Gen Intern Med. 2011; 26(8): 939-942, doi: 10.1007/s11606-011-1658-0, indexed in Pubmed: 21347876.

9. Fleet JC, Schoch RD. Molecular mechanisms for regulation of intestinal calcium absorption by vitamin D and other factors. Crit Rev Clin Lab Sci. 2010; 47(4): 181-195, doi: 10.3109/10408363.2010.536429, indexed in Pubmed: 21182397.

10. Christakos S, Ajibade DV, Dhawan P, et al. Vitamin D: metabolism. Endocrinol Metab Clin North Am. 2010; 39(2): 243-253, doi: 10.1016/j. ecl.2010.02.002, indexed in Pubmed: 20511049.

11. Nijenhuis T,Hoenderop JGJ, Bindels RJM. TRPV5 and TRPV6 in $\mathrm{Ca}(2+)$ (re) absorption: regulating $\mathrm{Ca}(2+)$ entry at the gate. Pflugers Arch. 2005; 451(1): 181-192, doi: 10.1007/s00424-005-1430-6, indexed in Pubmed: 16044309.

12. van de Graaf SFJ, Hoenderop JGJ, Bindels RJM. Regulation of TRPV5 and TRPV6 by associated proteins. Am J Physiol Renal Physiol. 2006; 290(6): F1295-F1302, doi: 10.1152/ajprenal.00443.2005, indexed in Pubmed: 16682485.

13. Hulter H HN. Effects and interrelationships of PTH, Ca2+, vitamin D, and Pi in acid-base homeostasis. Am J Physiol. 1985; 248(6 Pt 2): F739F752, doi: 10.1152/ajprenal.1985.248.6.F739, indexed in Pubmed: 2988344

14. Arnett TR. Extracellular pH regulates bone cell function. J Nutr. 2008; 138(2): 415S-418S, indexed in Pubmed: 18203913.

15. Kallas M, Green F, Hewison M, et al. Rare causes of calcitriol-mediated hypercalcemia: a case report and literature review. J Clin Endocrinol Metab. 2010; 95(7): 3111-3117, doi: 10.1210/jc.2009-2673, indexed in Pubmed: 20427501.

16. Cusano NE, Rubin MR, Sliney J, et al. Mini-review: new therapeutic options in hypoparathyroidism. Endocrine. 2012; 41(3): 410-414, doi: 10.1007/s12020-012-9618-y, indexed in Pubmed: 22311174.

17. Austin LA, Heath H. Calcitonin: physiology and pathophysiology. N Engl J Med. 1981; 304(5): 269-278, doi: 10.1056/NEJM198101293040505, indexed in Pubmed: 7003392. 